\title{
Practicum Learning Techniques in Brassica chinensis Pesticide Contamination Test on UISU FKIP Biology Students 2018-2019
}

\author{
Yusri Fefiani \\ Faculty of Teachers Training and Education, North Sumatera Islamic University, Medan, 20217, Indonesia \\ yusrifefiani@fkip.uisu.ac.id \\ ${ }^{*}$ Corresponding Author \\ Whatsapp Number [ +6282311642787]
}

How to Cite : Fefiani, Y. (2019). Practicum Learning Techniques in Brassica chinensis Pesticide Contamination Test on UISU FKIP Biology Students 2018-2019. International Journal for Educational and Vocational Studies, 1 (5), 519-523

\section{ARTICLE HISTORY}

Received: 9 July 2019

Revised: 27 July 2019

Accepted: 21 August 2019

\section{KEYWORDS}

Practicum Learning Techniques;

Brassica chinensis;

Pesticide Contamination:

Learning outcome test;

\begin{abstract}
The research test was carried out at the Biology Laboratory FKIP UISU. The study design used was a Completely Randomized Design (CRD) with 3 treatment tests and five replications, as a comparison of each treatment test used control. This study aims to determine the content of pesticides in Brassica chinensis in Medan city markets, whether pesticides are contaminated or not, and to determine student learning outcomes in biochemical subjects in additives and contaminants in food.In this study, the mortality of $\mathrm{C}$. binotalis larvae was observed in each treatment test, starting from observations on Brassica chinensis leaf samples taken from control, then on Brassica chinensis leaf samples taken from Sambas market, Simpang Limun market, Halat market, and market Like Crowded. Observations were made at 6, 12, 24, 48, and 72 hours after application. The area of leaf damage was observed after 72 hours of application in each treatment test. Likewise, larval weight gain was calculated after 72 hours of application.After 72 hours of treatment test, the highest larval mortality occurred in Brassica chinensis samples taken from the crowded market at $6.22 \%$, with the lowest larval weight gain of $570 \mathrm{mg}$, and with the least area of leaf damage that was $1,169 \mathrm{~mm} 2$. While the lowest larval mortality after 72 hours of treatment test occurred in Brassica chinensis samples taken from the control at $0.89 \%$, with the highest larval weight gain of $588.8 \mathrm{mg}$, and with the most extensive leaf damage area of $5,486.3 \mathrm{~mm} 2$.Before conducting biochemical learning on material additives and contaminants in food to students, a pre-test was made to students, and the average value of student learning outcomes during the pre-test was 60.26 with a standard deviation of 10.09 . Whereas after the learning material has been submitted and conducted a post test the average value of student learning outcomes has increased by 74.85 with a standard deviation of 6.25 .
\end{abstract}

This is an open access article under the CC-BY-SA license.

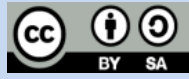

\section{INTRODUCTION}

Brassica chinensis contains nutrients that are complete enough so that when consumed it is very good for maintaining a healthy body. The content contained in Brasca chinensis is calories, protein, fat, carbohydrates, fiber, Ca, P, Fe, Vitamin A, Vitamin B, and Vitamin C. According to BPS (2018) consumption of mustard has increased from year to year, and in in 2016 mustard production reached 193.7 tons, this figure is very high when compared with other vegetables such as spinach, tomatoes, and kale. There are many markets in the city of Medan that sell Brassica chinensis. Brassica chinensis in the Medan city markets are mostly taken from the wholesale market in Simpang Selayang, Medan Tuntung District, and the wholesale market is also a mustard distributor from Berastagi.

As we know that every crop on agricultural land, especi- ally in Berastagi, is generally sprayed with pesticides because the role of pesticides in increasing agricultural production is undeniable. One of the plants that is often sprayed with pesticides is a vegetable plant, especially the Brassica chinensis plant. This happens because the shape and structure of the Brassica chinensis plant allows caterpillars to nest between their leaves and also because Brassica chinensis has many natural enemies from insects. The effect of the correct use of pesticides will be very quickly seen in a decrease in pest populations and plant diseases. The benefits of pesticides that are felt very quickly make farmers hang too high hopes on pesticides. As a result, farmers make pesticides the only mainstay in controlling pests and plant diseases. Due to limited knowledge, the use of pesticides is often mistaken. For example, increasing doses and concentrations beyond the rules, mixing various types of pesticides, ignoring work 
safety rules, and so on. Pesticides sprayed on plants will certainly leave a residue. Pesticide residues are found in all parts of the plant such as stems, leaves, fruits and roots. Even though they have been washed or cooked, these pesticide residues are still found in food. Pesticide residues are active in the human body so they will have a negative impact on human health that consumes vegetables that contain pesticide residues continuously. Syakir (2011) explained that healthy and environmentally friendly agricultural products are already a guideline of the global market (AFTA, APEC, and WTO), with eco-labeling attributes, nutritional attributes, and safe consumption (food safety attributes).

Many people assume that to get good quality food such as vegetables, can be obtained by buying in modern shopping places such as hyper markets. This is because the majority of human consumption materials such as food sold on the hyper market are imported from outside the region and even from abroad which are believed to have better quality than the local market. In fact, if examined deeper, not all food ingredients of local production are of low quality. Food imported from outside the region also does not guarantee $100 \%$ better quality than local production. The process of propagation in the laboratory through testing trials for students is needed in producing fresh and high quality mustard greens. Tests conducted by students on laboratory techniques in the laboratory turned out to give satisfactory results.

\section{METHODS}

\subsection{Research Location}

The location of the study was conducted in Biology Laboratory FKIP UISU. Start from March 2019 until May 2019.

\subsection{Materials and Tools}

\section{Materials}

1. Crossidolomia binotalis instar larvae I: 75 tail

2. Chicory leaves (Brassica chinensis): $1 \mathrm{~kg}$

3. Honey: 1 bottle

4. Aquades: 1 liter

5. Land

Tools

1. Petri dishes: 15 pieces

2. Filter paper: 1 box

3. Gauze: 1 box

4. Hygrometer: 1 piece

5. Vegetable scissors: 1 piece

6. Small brush: 1 piece

7. Plastic jars: 5 pieces

8. Cotton: 1 pack

\section{Stationery}

10. Camera

\subsection{Population and Sample}

The population in this study were all mustard greens (Brassica chinensis) which were sold in Simpang Limun market, Halat market, Sambas market, and Suka Ramai market in Medan. The sample in this study was mustard greens using purposive sampling technique that is as many as 5 samples with the criteria of mustard greens (Brassica chinensis) which are more traded and vegetables that look perfect in terms of physical namely leaves without holes.

\section{4 Research Design, Work Procedures, and Observations}

\section{Research Design}

This study uses Semester level II as a research subject, and pretest treatment as a variable factor $\mathrm{T} 1$ and treatment as a variable $\mathrm{Y}$, then posttest as a variable $\mathrm{T} 2$.

\section{Work Procedure}

Crossidolomia binotalis larvae obtained from post-harvest Brassica chinensis vegetable gardens are kept in plastic jars and fed with Brassica chinensis leaves, at the top of the jars covered with gauze. The pupae that is formed remains maintained in a jar until it becomes an imago. During the imago phase, Crossidolomia binotalis is fed honey placed on cotton that has been mixed with a little aquades. Then the eggs produced from the same time are kept until they reach Instar I.

\section{Application}

1. Prepare pieces of Brassica chinensis leaves for larva food of a certain size.

2. Place the pieces of Brassica chinensis leaves in a petri dish. To prevent the dryness of the leaves, the petri dish was previously coated with moistened filter paper.

3. The instar I larvae of Crossidolomia binotalis, which are of the same size and age, are infested on Brassica chinensis leaves, after the larvae are fasted for 2-4 hours.

4. For control, Brassica chinensis leaves are dipped in distilled water for 5 minutes, then air dried until the leaves are no longer wet.

\section{Observations}

\section{Death of the Larva}

Observation of larval death of Crossidolomia binotalis was carried out $6,12,24,48,72$ hours after application (starting at $08.00,14.00,20.00,02.00$, etc. until reaching 72 hours). Larvae are said to die if the larvae when touched with the tip of the brush are no longer moving or stationary. The percentage of larval mortality is calculated using the $\mathrm{Dj}$ formula. Prijono namely: 
$\mathrm{I}=\mathrm{a} / \mathrm{b} \times 100 \%$

where: $\mathrm{I}=$ Percentage of larval death

$\mathrm{a}=$ Number of dead larvae

$\mathrm{b}=$ total larvae

\section{Larva weight}

The average weight of the first instar larvae before application, namely by weighing ten instar larvae to one other than the larvae for treatment, and the average weight of larvae after completion of the study, calculated the weight of the larvae still alive from each treatment (including control).

\section{Area of Damage}

Calculate the area of damage to mustard greens eaten by crossidolomia binotalis larvae using millimeter paper.

\subsection{Data Analysis Techniques}

\section{Pre -Test}

Pre test is a test conducted at the beginning of learning of the material taught before the teaching and learning process takes place which aims to determine the basic abilities of students to additives substances and contaminants in food with a total of 5 questions (items) and questions in the form of essays.

\section{Post -Test}

Post test is a test conducted at the end of learning about the material that has been studied which aims to determine student learning outcomes after studying material additives and contaminants in food. The test in this study is in the form of essays with a total of 10 questions (items). This can be seen through the Post Test table (Blue print) below:

$(\mathrm{x})=\left(\sum\right.$ (fi .xi $\left.) /\left(\sum \mathrm{fi}\right)\right)$

Information :

(x): Mean for classified data

$\sum$ fi: Number of data / samples

fi xi: Product multiplication between fi at each data interval with a class sign (Xi). The class sign (Xi) is the average of the lowest and highest values for each data interval.

\section{RESULTS AND DISCUSSION}

The following are the results of observations of the treatment test: table 1.The larvae died an average of 6 hours after the test of the presence or absence of pesticide contamination on the leaves of Brassica chinensis.

Data and results of larval mortality 6 hours after the treatment test can be seen in the above table. The average results show that the lowest larval mortality rate is that of Brassica chinensis samples taken from control, inversely proportional to Brassica chinensis samples taken from Halat market which shows the highest mortality rate of larvae. Brassica chinensis samples taken from Suka Ramai market showed the second highest larval mortality after samples taken from the Halat market, and followed by Brassica chinensis samples taken from the Simpang Limun market, then Brassica chinensis samples taken from the Sambas market.

Table 1. Larva died after 6 hours test treatment :

\begin{tabular}{|c|c|c|c|c|c|}
\hline \multirow{2}{*}{ Treatment } & \multicolumn{3}{|c|}{ Repetition } & \multirow{2}{*}{ Number of Deaths } & \multirow{2}{*}{ Death Rate } \\
\hline & I & $\|$ & III & & \\
\hline $\mathrm{K}$ & 0 & 0 & 0 & 0 & 0 \\
\hline BS PS & 0 & 1,33 & 1,33 & 2,66 & 0,89 \\
\hline BS PSL & 1,33 & 2,67 & 1,33 & 5,33 & 1,78 \\
\hline $\mathrm{BS} \mathrm{PH}$ & 2,67 & 2,67 & 4 & 9,34 & 3,11 \\
\hline BS PSR & 2,67 & 1,33 & 2,67 & 6,67 & 2,22 \\
\hline
\end{tabular}

Table 2. Larva died after 12 hours test treatment

\begin{tabular}{|c|c|c|c|c|c|}
\hline \multirow[b]{2}{*}{ Treatment } & \multicolumn{3}{|c|}{ Repetition } & \multirow[b]{2}{*}{ Number of Deaths } & \multirow[b]{2}{*}{ Death Rate } \\
\hline & । & $\|$ & III & & \\
\hline $\mathrm{K}$ & 0 & 0 & 0 & 0 & 0 \\
\hline BS PS & 1,33 & 1,33 & 1,33 & 4 & 1,33 \\
\hline BS PSL & 1,33 & 2,67 & 1,33 & 5,33 & 1,78 \\
\hline $\mathrm{BS} \mathrm{PH}$ & 2,67 & 4 & 4 & 10,67 & 3,56 \\
\hline BS PSR & 2,67 & 4 & 4 & 10,67 & 3,56 \\
\hline
\end{tabular}


Table 3. Larva died after 24 hours test treatment

\begin{tabular}{|c|c|c|c|c|c|}
\hline \multirow{2}{*}{ Treatment } & \multicolumn{3}{|c|}{ Repetition } & \multirow{2}{*}{ Number of Deaths } & \multirow{2}{*}{ Death Rate } \\
\hline & I & $\|$ & III & & \\
\hline $\mathrm{K}$ & 1,33 & 0 & 0 & 0 & 0 \\
\hline BS PS & 1,33 & 1,33 & 1,33 & 4 & 1,33 \\
\hline BS PSL & 1,33 & 4 & 1,33 & 6,66 & 2,22 \\
\hline $\mathrm{BS} \mathrm{PH}$ & 4 & 5,33 & 5,33 & 14,66 & 4,89 \\
\hline BS PSR & 5,33 & 4 & 5,33 & 14,66 & 4,89 \\
\hline
\end{tabular}

Table 4. Larva died after 48 hours test treatment

\begin{tabular}{|c|c|c|c|c|c|}
\hline \multirow{2}{*}{ Treatment } & \multicolumn{3}{|c|}{ Repetition } & \multirow{2}{*}{ Number of Deaths } & \multirow{2}{*}{ Death Rate } \\
\hline & 1 & II & III & & \\
\hline K & 1,33 & 0 & 1,33 & 2,66 & 0,89 \\
\hline BS PS & 1,33 & 1,33 & 1,33 & 4 & 1,33 \\
\hline BS PSL & 1,33 & 4 & 1,33 & 6,66 & 2,22 \\
\hline $\mathrm{BS} \mathrm{PH}$ & 4 & 5,33 & 5,33 & 14,66 & 4,89 \\
\hline BS PSR & 5,33 & 5,33 & 6,67 & 17,33 & 5,78 \\
\hline
\end{tabular}

Table 5. Larva died after 72 hours test treatment

\begin{tabular}{|c|c|c|c|c|c|}
\hline \multirow{2}{*}{ Treatment } & \multicolumn{3}{|c|}{ Repetition } & \multirow{2}{*}{ Number of Deaths } & \multirow{2}{*}{ Death Rate } \\
\hline & I & $\|$ & III & & \\
\hline $\mathrm{K}$ & 1,33 & 0 & 1,33 & 2,66 & 0,89 \\
\hline BS PS & 2,67 & 1,33 & 1,33 & 5,33 & 1,78 \\
\hline BS PSL & 1,33 & 4 & 1,33 & 6,66 & 2,22 \\
\hline $\mathrm{BS} P \mathrm{PH}$ & 4 & 5,33 & 6,67 & 16 & 5,33 \\
\hline BS PSR & 5,33 & 6,67 & 6,67 & 18,67 & 6,22 \\
\hline
\end{tabular}

Information:

$\mathrm{K}=$ Brassica chinensis free of pesticides as a control

BS PS = Brassica chinensis originating from the Sambas market

BS PSL = Brassica chinensis originating from the Simpang Limun market

BS PH = Brassica chinensis originating from Halat market

BS PSR = Brassica chinensis originating from Suka Ramai market

\section{RESULT OBSERVATION}

In from the graph it can be seen that in repetition III where Brassica species taken from the Halat market show the highest lift of 4 , and the highest number of deaths in larvae which also have a direct impact on the average number of larval deaths.

Data and the average yield of larvae death 12 hours after the treatment test can be seen in the table below. The average results showed that the lowest larval mortality rates were Brassica chinensis samples taken from control, while Brassica chinensis samples taken from the Suka Ramai market and Halat market showed the highest larval mortality rates, followed by Brassica chinensis samples taken from the Simpang Limun market, then Brassica chinensis samples taken from the Sambas market. Data and results of larval mortality 24 hours after the treatment test can be seen in the table below. The average results showed that the lowest larval mortality rates were Brassica chinensis samples taken from control, while the highest larval mortality rates came from Brassica chinensis samples taken from Halat and Suka Ramai markets, followed by Brassica chinensis samples taken from the market. Simpang Limun, then Brassica chinensis samples taken from the Sambas market. Data and the average yield of larvae 48 hours after the treatment test can be seen in the table below. The average results show that the lowest larval mortality rate is Brassica chinensis samples taken from control, while the highest larval mortality rate comes from Brassica samples chinensis taken from Suka Ramai market, followed by Brassica chinensis samples taken from Halat market, then Brassica chinensis samples taken from Simpang Limun market, and Brassica chinensis taken from 
Sambas market. Data and the average yield of larvae death 72 hours after the treatment test can be seen in the table below. The average results showed that the lowest larval mortality rate was Brassica chinensis samples taken from control, while the highest larval mortality rates came from Brassica chinensis samples taken from the Suka Ramai market, followed by Brassica chinensis samples taken from Halat market, then Brassica chinensis samples taken from the Simpang Limun market, and Brassica chinensis samples taken from the Sambas market.

\section{CONCLUSION}

Based on the results of the study it can be concluded that:

1. There are pesticide contents in several markets in the city of Medan with an indicator of mortality from larval Crossidolomia binotalis.

2. The highest mortality of Crossidolomia binotalis larvae occurred in Brassica chinensis samples taken from the Suka Ramai market with an average of $6.22 \%$ after 72 hours of application, then followed by Brassica chinensis samples taken from Halat market, Simpang Limun market, market Sambas, respectively of $5.33 \%, 2.22 \%$ and $1.78 \%$.

3. The higher the content of pesticides in the leaves, the higher the mortality rate of larvae, the lower the weight gain of larvae, and the less extensive damage that occurs on the leaves of Brassica chinensis because it is not eaten by Crossidolomia binotalis larvae.

4. After delivering learning material related to the author's research to students, student learning outcomes show good results. If before the learning material is delivered the average pre-test results of the students show the number 60.26 with a standard deviation of 10.09 , then after the learning material is delivered and the post test results the average post-test results of the students show the number 74.85 with the standard deviation 6.25 .

\section{REFERENCES}

Almatsier, S. (2002). Prinsip Dasar Ilmu Gizi. Jakarta : Gramedia Pustaka Utama.

Anonim. (2007). Hama Pada Sayuran, Kacang-kacangan, dan Umbi-umbian.

http://ujianoke.blogspot.com/2012/10/hama-pada-sayu ran-kacang-kacangan-dan.html (Diakses tanggal 08 Februari 2019)

Bernard. et al. (2016). Identifikasi Klorpirifos Dalam Sawi Hijau Di Pasar Terong Dan Swalayan Mtos Makassar. Jurnal Unhas. hlm 2.

BPS Kota Surabaya (2018). Surabaya dalam Angka Tahun 2016. BPS Surabaya.

Cahyono, B. (2003). Teknik dan Strategi Budi Daya Sawi Hijau (Pai-Tsai). Yayasan Pustaka Nusantara, Yogyakarta
Departemen Pertanian. Pengenalan Pestisida. Jakarta: Depkes RI; 2011.

Dhavie. (2010). Pestisida Merusak Lingkungan. http://dhavie.student.umm.ac.id. (Diakses tanggal 05 Februari 2019).

Djojosumarto, Panut. (2004). Teknik Aplikasi Pestisida Pertanian. Yogyakarta : Kanisius.

Ekha, Ivasta. (1988). Dilema Pestisida Tragedi Revolusi Hijau. Yogyakarta : Kanisius.

Fefiani, Yusri. (2014). SERANGGA Determinasi Famili Serta Pengelolaan Hama. Bandung : Cipta Pustaka Media Perintis.

Haryanto, E. (2001). Sawi \& Selada. Jakarta : Penebar Swadaya.

Haryanto, E. T. Suhartini, E. Rahayu. (1995). Sawi dan Selada. Jakarta : Penebar Swadaya.

Haryanto, W., T. Suhartini, dan E. Rahayu. (2007). Teknik Penanaman Sawi dan Selada Secara Hidroponik. Jakarta : Penebar Swadaya.

Kimball, Jonn. W. (1983). Biologi 5th edition. Diterjemahkan oleh Soetarmi, S. T dan Nawangsari Sugiri. 1990. Erlangga : Jakarta.

Mahyuni, Eka Lestari. (2015). Faktor Risiko Dalam Penggunaan Pestisida Terhadap Keluhan Kesehatan Pada Petani Di Kecamatan Berastagi kabupaten Karo 2014. Jurnal Usu. (Volume 9 Nomor 1): hlm 82.

Novizan. (2007). Petunjuk Pemakaian Pestisida. Jakarta : Agro Media.

Peraturan Pemerintah Republik Indonesia Nomor 7 Tahun 1973 tentang Pengawasan atas Peredaran, Penyimpanan dan Penggunaan Pestisida. 1973. Jakarta : Sinar Grafika

Prijono, Dj. (1988). Pengujian Insektisida (penuntun praktikum). Jurusan Hama dan Penyakit Tumbuhan FP IPB Bogor.

Rukmana, Rahmat. (1994). Bertanam Petsai \& Sawi. Yogyakarta: Kanisius.

Subiyakto. (1991). Pengantar Serangga, Hama, Penyakit, dan Gulma Padi. Yogyakarta: Kanisius.

Suhartini., IGP Suryadarma \& Budiwari. (2017). Pemanfaatan Pestisida Nabati Pada Pengendalian Hama Plutella xylostella Tanaman Sawi (Brassica juncea L.) Menuju Pertanian Ramah Lingkungan. Jurnal Sains Dasar. Yogyakarta. Volume 6 Nomor 1 : hlm 37

Sulistiyono, Luluk. (2004). Dilema Penggunaan Pestisida Dalam Sistem Pertanian Tanaman Hortikultura di Indonesia. Sekolah Pasca Sarjana Institut Pertanian Bogor.

Quijano, R. dan Sarojeni V Rengam. (1999). Pestisida Berbahaya Bagi Kesehatan. Solo : Yayasan Duta Alam.

Wudianto R. (2001). Petunjuk penggunaan Pestisida. Jakarta: Penebar Swadaya.

Wudianto, Rini. (2005). Petunjuk Penggunaan Pestisida. Edisi Revisi. Jakarta: Penebar Swadaya. 